\title{
Gunung Kawi: Olahan Ketela Ungu Memberdayakan Masyarakat
}

\author{
Farida Nur Kumala', Muhammad Nur Hudha², Sudi Dul Aji', \\ Universitas Kanjuruhan Malang ${ }^{1,2,3}$ \\ faridankumala@unikama.ac.id*, muhammadnurhudha@unikama.ac.id, sudi@unikama.ac.id
}

\begin{abstract}
Purple sweet potato Gunung Kawi is only sold raw, the price is very cheap. This causes the farmers to suffer losses. On the other hand, quite a lot of Wonosari Gunung Kawi residents become female migrant worker, because there are not enough producers in the village to meet the residents' needs. Based on that, the processing of purple sweet potato Gunung Kawi is needed to be developed into an effort that can absorb labor. The purpose of this service is to produce a purple sweet potato product business for residents of Wonosari Gunung Kawi. The service method used is through three stages, the first stage is preparation for coordination and outreach activities to partners. The second stage is implementation phase of training carried out training on the processing of purple sweet potato Gunung Kawi into several products such as sticks, bakpia and brownies from purple sweet potato of Gunung Kawi. The third stage is evaluation and assistance. The instruments in this service were interview sheets and activity observations. The results of the service show that the community has been able to produce and package products that are ready for sale and according to health standards.
\end{abstract}

Keywords: Gunung Kawi; Stik telo ungu; Bakpia Telo Ungu; Female migrant worker.

\begin{abstract}
Abstrak
Selama ini telo ungu gunung kawi hanya dijual secara mentah sehingga harga jual telo ungu sangat murah. Hal ini menyebabkan petani kebun telo mengalami kerugian khususnya pada musim tertentu. Di lain sisi, warga Wonosari Gunung Kawi cukup banyak yang menjadi Tenaga Kerja Wanita (TKW) karena penghasil di desa yang belum cukup untuk memenuhi kebutuhan warga. Berdasarkan hal tersebut diperlukan pengolahan Sumber Daya Alam (SDA) telo ungu yang dikembangkan menjadi suatu usaha yang dapat menyerap tenaga kerja. Tujuan pengabdian ini adalah menghasilkan usaha pengolahan telo ungu bagi warga Wonosari Gunung Kawi. Metode pengabdian yang digunakan adalah melalui tiga tahapan yakni persiapan dilakukan kegiatan koordinasi dan sosialisasi terhadap mitra, tahap kedua yakni tahap pelaksanaan pelatihan dilakukan pelatihan pengolaha telo ungu gunung kawi menjadi beberapa produk yakni stik, bakpia dan brownies telo ungu gunung kawi. Tahap ketiga adalah evaluasi daan pendampingan. Instrumen yang digunakan pada kegiatan pengabdian ini adalah lembar wawancara dan observasi kegiatan. Hasil pengabdian menunjukkan bahwa masyarakat telah mampu memproduksi dan mengemas stik, brownies dan bakpia menjadi produk yang siap untuk dijual dan sesuai standar kesehatan.
\end{abstract}

Kata kunci: Gunung Kawi; Stik telo ungu; Bakpia Telo Ungu; TKW. 


\section{A. PENDAHULUAN}

Kesejahteraan masyarakat desa merupakan suatu hal yang harus dilakukan oleh pemerintah. Pemberdayaan dalam suatu masyarakat merupakan salah satu kecenderungan baru dalam paradigma pembangunan di Indonesia (Eko Sugiharto, 2007). Pertumbuhan ekonomi masyarakat juga dapat mingkatkan penyerapan tenaga kerja serta kesejahteraan masyarakat (Sulistiawati, 2012).

Gunung kawi merupakan daerah yang memiliki sumber daya alam perkebunan yang melimpah. Hasil perkebunan masyarakat di sana adalah ubi kuning dan ungu, ketela, kopi dan cengkeh. Ketela khas gunung kawi terkenal akan kelezatannya, namun selama ini pengembangan dan pengelolaan olahan ketela di daerah Gunung Kawi masih terbatas sehingga wisatawan dari Gunung Kawi kurang variatif dalam membawa oleh-oleh dari daerah gunung kawi. Oleh - oleh wisatawan selama ini adalah Ubi ungu dan kuning (ketela ungu dan ketela kuning) yang diperoleh secara mentah atau olahan goreng dan rebus.

Fakta di lapangan menunjukkan konsumsi makanan umbi-umbian mengalami penurunan. Padahal konsumsi makanan umbi-umbian sangat baik untuk kesehatan. Hal ini dikarenakan pada umbi-umbian indek glikemiknya yang rendah, sehingga mampu mencegah terjadinya penyakit diabetes (Ariani, 2010).

Sementara itu tingkat masyarakat untuk mengkonsumsi olahan yang berupa kue sangat tinggi. Pembuatan brownies merupakan salah satu solusi yang sangat bagus (Putri, 2013). Brownies merupakan salah satu makanan yang popular di masyarakat (Sumpah \& No, 2015).

Di bidang industri makanan, brownies merupakan panganan yang banyak diminati oleh konsumen (Putri, 2013). Berdasarkan data Statistik Konsumsi Pangan Tahun 2015, konsumsi kue basah pada Tahun 2015 mencapai 1,245 kg/Kapita/Minggu (Putri, 2013). Produk olahan broeniea sudah banyak dijumpai masyarakat dengan berbagai variasi (Machmud, Kurniawati, \& Haetami, 2012)(Haliza, Kailaku, \& Yuliani, 2017).

Selain brownies olahan yang bisa dilakukan oleh bahn baku ketela ungu adalah pembuatan stik ketela. Olahan ketela berupa stik juga bias dijadikan variasi dalam pembuatan camilan (Pranata, Ghufron, \& Tri, 2018). Produk oalahan stik sudah dikenal oleh masyarakat (Suladra, 2017). Pada umumnya olahan ini disajikan dalam berbagai bentuk kemasan. Stik dalam perkembangannya dapat dilakukan dari berbagai macam macam bahan baku. Ketela merupakan salah satu bahan baku yang bisa dimanfaatkan untuk pembuatan oalahan stik ini.

Ketela juga bisa dimanfaatkan untuk pembuatan olahan lain selain itu. Olahan tersebut dapat berupa olahan pembuatan bakpia. Produk bakpia selama ini sudah berbagai macam variasi yang dikembangkan. Proses pembuatan bakpia meliputi beberapa tahap, yaitu pembuatan adonan kulit, pembuatan isi/kumbu, pencetakan, pemanggangan dan pendinginan (Suladra, 2017).

Berdasarkan pemaparan tersebut sangat cocok jika dikembangkan suatu olahan produk dari ketela untuk meningkatkan daya beli wisatawan yang datang ke daerah Gunung Kawi. Harapannya agar olahan ketela ungu bisa divariasi dalam bentuk dan di konsumsi masyarakat sekitar untuk meningkatkan kesejahteraan masyarakat. 


\section{B. PELAKSAAAN DAN METODE}

Metode yang dilakukan dalam pengabdian ini adalah dengan pendampingan dan pemanfaatan teknologi tepat guna. Metode yang digunakandiawali dari kegiatan analisis kebutuhan. Kegiatan analisis kebutuhan bertujuan untuk mengetahui permasalahan yang ditemui mitra. Instrument yang digunakan pada kegaitan ini menggunakan lembar observasi dan wawancara. Hasil temuan kegiatan analisis yang diljadikan dasar untuk melasanakan program kemitraan kepada masyarakat.

Tahapan yang kedua adalah tahap persiapan. Pada tahap persiapan dilakukan kegiatan koordinasi dan sosialisasi kepada waraga masyarakat desa Wonosari yang terdiri dari kepala desa dan ketua PKK desa Wonosari Kecamatan Wonosari Kabupaten Malang.

Tahap persiapan dilanjutkan dengan tahapan pelaksanaan. Pada tahap pelaksanaan dilakukan pelatihan yang terdiri dari:a). Pendahuluan yang diawali dnegan memotivasi mitra dalam berwirausaha dan juga penjelasan tentang telo ungu dan olahannya. Selanjutnya dilakukan tahap pengolahan. Pada tahap pengaolahan pengabdi bersama mitra bersama sama untuk melakukan kegiatan pengolahan telo ungu menjadi beberapa olahan produk seperti stik, bronies dan bakpia telo ungu.

Pada tahap pelaksanaan setelah kegiatan pembuatan produk telo ungu, selanjutnya dilakukan kegiatan pengemasan untuk membekali mitra dalam melakukan pengemasan yang sesuai dengan standar yang ditentukan. Pada kegiatan ini dilakukan pelatihan tentang syarat pengemasan dan cara melakukan pengemasan sesuai standar dari dinkes.

Tahapan terakhir adalah tahapan pendampingan dan evaluasi program. Tahap ini dilakukan setelah mitra mampu mengolah beberapa kali secara mandiri. Selanjutnya dari kegiatan tersebut dilakukan pendampingan untuk mengetahui persamasalahan mitra ketika bekerja secara mandiri dan dilakukan evaluasi jika terdapat kesalahan selama pengembangan produk secara mandiri.

\section{HASIL DAN PEMBAHASAN}

Hasil kegiatan program kemitraan kepada masyarakat dapat dijabarkan sebagai berikut:

Pada tahap analisis kebutuhan diketahui bahwa berdasarkan hasil wawancara terhadap kebutuhan masyarakat di Gunung kawi diperoleh sebuah data yang disajikan dalam Gambar 1.

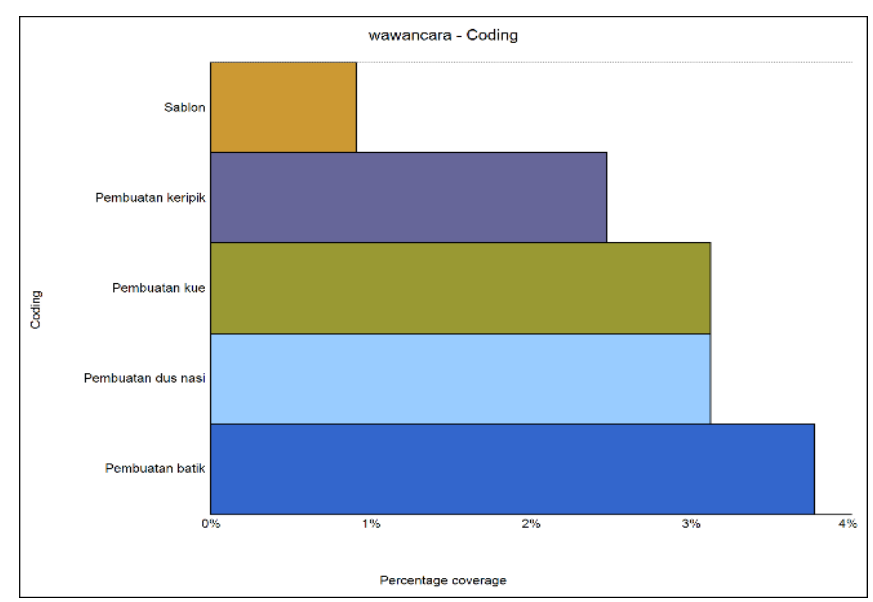

Gambar 1. Hasil wawancara

Berdasarkan hasil wawancara yang di analisis menggunakan software Nvivo12, dapat dilihat bahwa pelatihan di Desa Wonosari sudah sering dilakukan dinas UMKM atau dari Disperindag. Namun pelatihan tersebut tidak menyentuh dalam olahan ketela. Sehingga sangat tepat jika melakukan pelatihan menggunakan bahan baku ketela untuk meningkatkan pemasukan masyarakat sekitar. 
Berdasarkan hasil analisis kegiatan dilakukan persiapan. Pada tahap persiapan ini dilakukan kegiatan sosialisasi. Kegiatan sosialisasi ini meliputi kegiatan pemaparan pentingnya olahan ketela, sosialisasi pelatihan dan pendapmingan, dan kegiatan sosialisasi pemasaran. Sosialisasi dilakukan kepada seluruh masyarakat yang akan mengikuti pelatihan ini. Diantaranya adalah kepala desa, ketua PKK dan ketua UKM Ketela ungu gunung kawi. Sosialisasi ini bertujuan untuk meminta ijin dan menjabarkan program pendampingan yang akan dilakukan. Sosialisasi ini dilakukan secara langsung mapun tidak langsung (Herryanto \& Toly, 2013). Sosialisasi langsung adalah kegiatan sosialisasi dengan berinteraksi langsung dengan ahli pembuatan kue. Sedangkan sosialisasi tidak langsung dengan tidak atau sedikit melakukan interaksi dengan peserta. Contoh kegiatan sosialisasi tidak langsung antara lain sosialisasi melalui penyebaran buku/ booklet/ leaflet ataupun dengan membawa oalahan kue langsung kepada peserta.

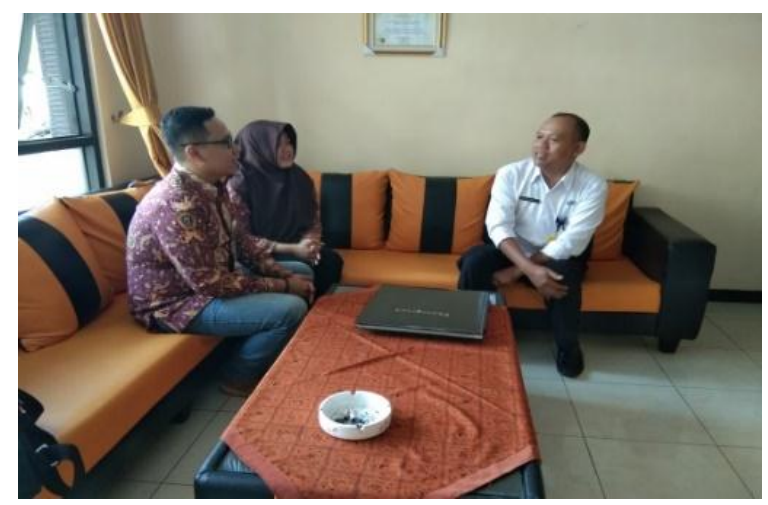

Gambar 2. Koordinasi mitra

Tahapan setelah persiapan adalah tahapan pelaksanaan. Pada tahap pelaksanaan dilakukan melalui kegiatan pelatihan. Kegiatan ini terdiri dari tiga kegiatan yang diawali dengan pendahuluan yang terdiri dari penjelasan tentang kewirausahaan, keuntuangan berwirausaha dan penjelasan tentang telo ungu serta olahannya. Berdasarkan kegiatan yang dilakukan masyarakat menjadi lebih antusias untuk berwirausaha.

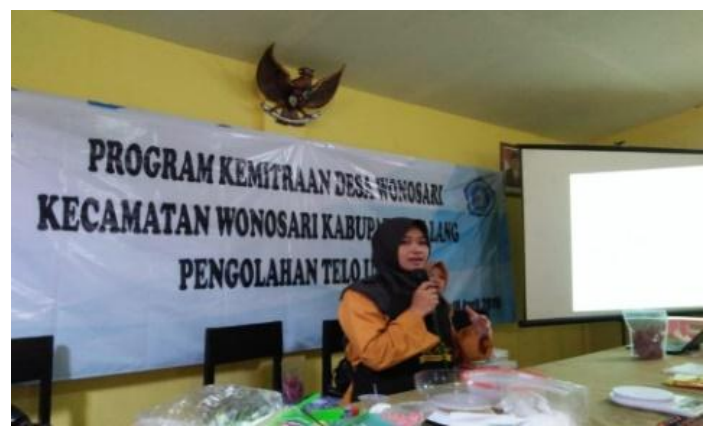

Gambar 3. Kegiatan pendahuluan

Kegiatan kedua pada tahap pelaksnaan berupa pembuatan olahan dengan bahan baku ketela ungu. Pelatihan yang diselenggarakan diantaranya adalah pembuatan brownies ketela ungu, pembuatan stik ketela ungu, dan pembuatan bakpia dengan bahan baku ketela ungu. Kegiatan pelatihan dilakukan dengan mendatangkan pakar food and baverage.

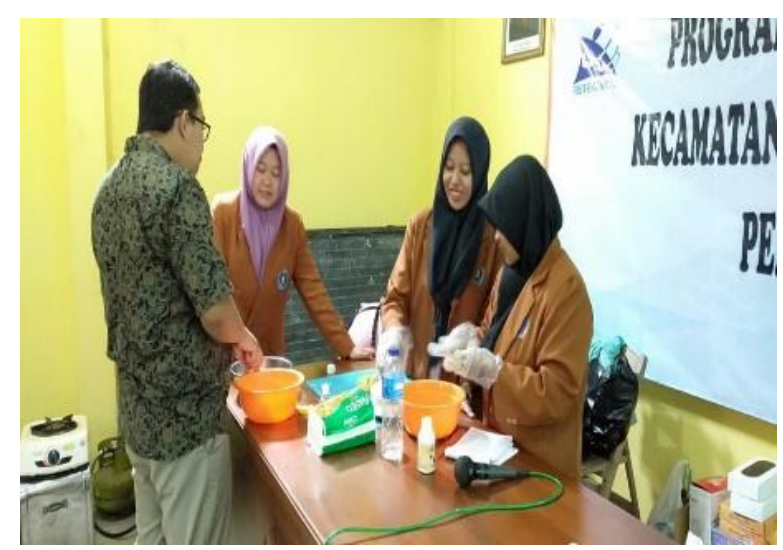

Gambar 4. Kegiatan pelatihan 


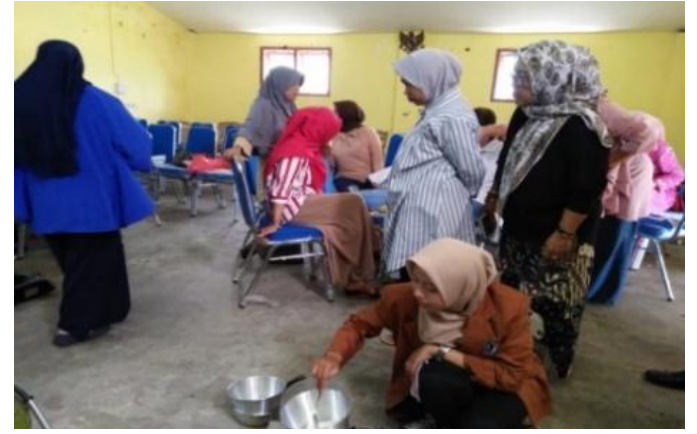

Gambar 5. Simulasi oleh mitra

Kegiatan terakhir adalah tahap pendampingan dan evaluasi program. Pendampingan dilakukan dengan cara pengawasan dan konsultasi peserta secara online maupun ofline. Hasil pendampingan menunjukkan bahwa mitra mengalami kendala dalam hal melakukan pemasaran, karena pemasaran hanya dilkukan disekitar warga saja. Selain itu kendala juga dihadapi mitra dalam memproduksi bakpia telo ungu.

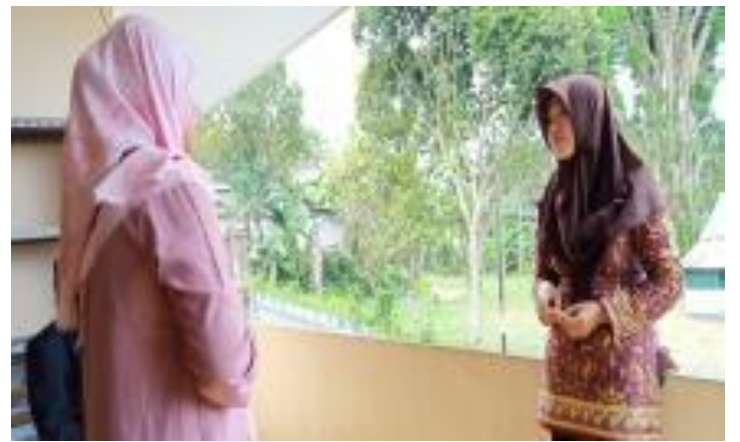

Gambar 6. Kegiatan pendampingan

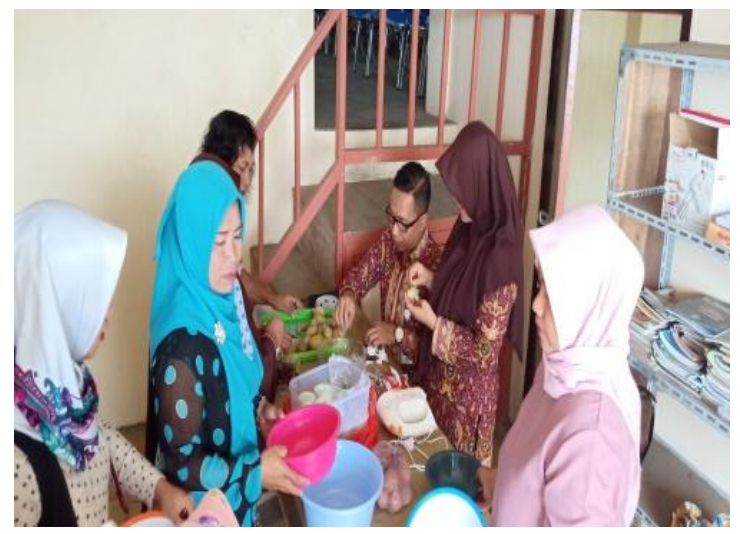

Gambar 7. Kegiatan pendampingan pembuatan produk
Pada kegiatan pendampingan pendamping berfungsi sebagai fasilitator, motivator dan katalisator. Peran yang harus dilakukan oleh seorang pendamping disesuaikan dengan ruang lingkup pendampingannya, peran-peran yang harus dimainkan pendamping adalah sebagai fasilitator, motivator dan katalisator (Kamil, 2010)

Kegiatan selanjutnya adalah melakukan pengurusan ijin dari Izin Produk Industri Rumah Tangga (P-IRT) UKM Indonesia ke dinas kesehatan Kabupaten Malang. Pengurusan Ijin P-IRT ini berfungsi untuk menguatkan pemasaran produk karena telah memiliki sertifikat ijin dagang dan juga meghindari kesamaan atau plagiasi merk/usaha yang digunakan.

Pengurusan Ijin PIRT dilakukan melalui beberapa tahapan yakni pendaftran ke dinkes (gambar 7), verifikasi data, workshop dinas kesehatan bagi pemiliki usaha, kunjungan lapangan/ survey (gambar 8) sebelum mendapatkan sertifikat. Survey dilakukan oleh dinas kesehatan untuk dilakukan pengecekan terhadap beberapa aspek yakni kebersihan, cara pengolahan, cara penyimpanan, penggunaan bahan dan alat serta cara pengemasan yang higienis.

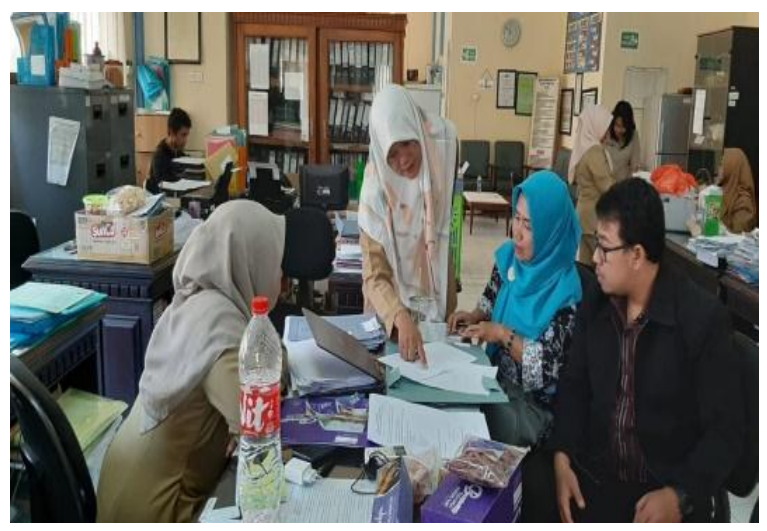

Gambar 8. Pendampingan PIRT 


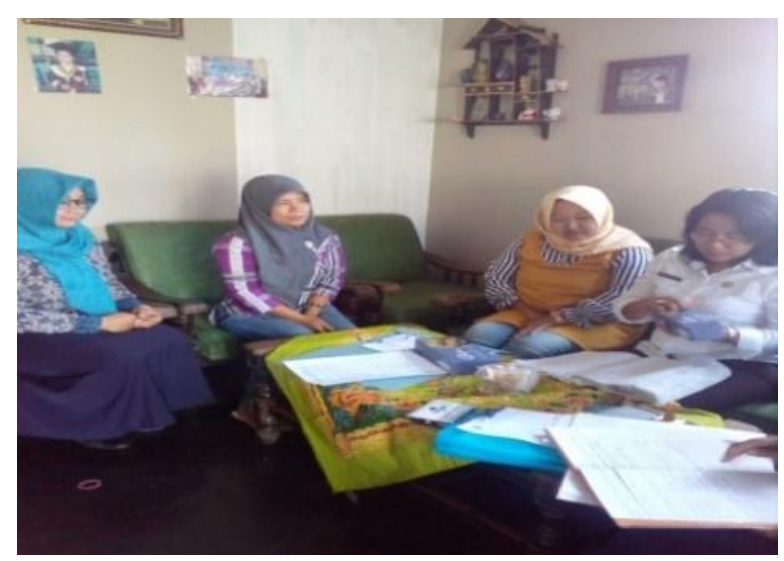

Gambar 9. Kegiatan Survey dari PIRT

Hasil dari kegiatan yang telah dilakukan sebelumnya saat ini masyarakat bersemangat berwirausaha hal ini disebabkan mitra telah mampu mengolah dan mengembangkan telo ungu yang selama ini kurang dimanfaatkan dengan baik oleh warga sekitar. Gambar hasil olahan telo ungu yang telah dikembangkan ditunjukkan pada Gambar 9 dan 10.

Kewirausahaan diartikan sebagai semangat, kemampuan, sikap, perilaku individu dalam menangani usaha atau kegiatan yang mengarah pada upaya mencari, menciptakan, menerapkan, cara kerja, teknologi, dan produk baru dengan mewujudkan efisiensi dalam rangka memberikan pelayanan yang lebih baik atau memperoleh keuntungan yang lebih besar (Drucker, 2005).

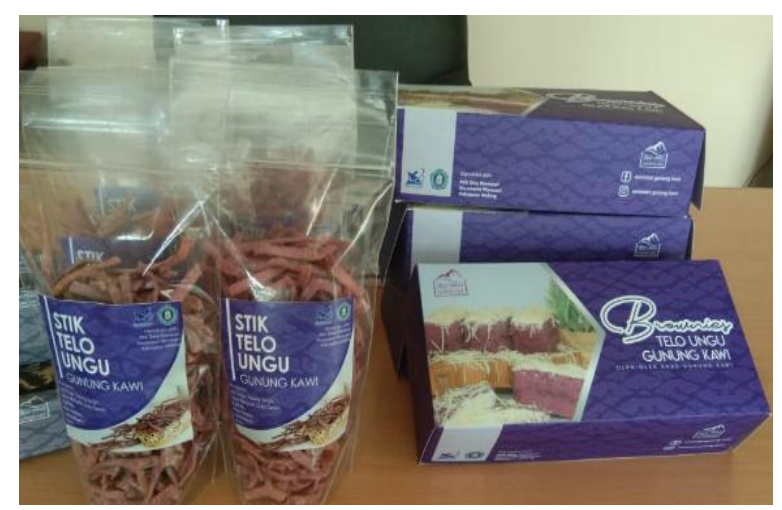

Gambar 10. Olahan telo ungu stik dan brownies telo ungu

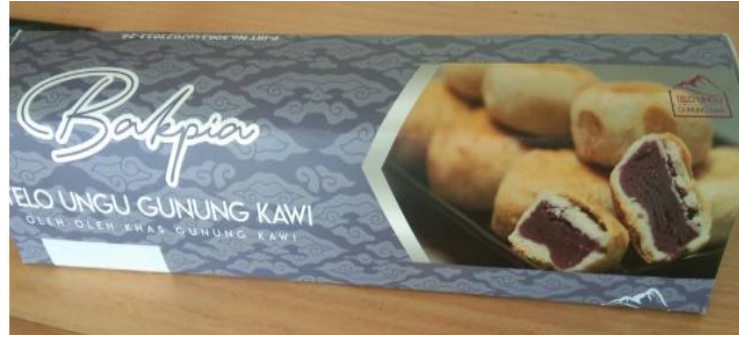

Gambar 11. Bakpia Telo Ungu

Selanjutnya berdasarkan hasil kegiatan produksi yang telah dilakukan diketahui bahwa, hasil dari penjualan kegiatan produksi telah terjadi peningkatan keterampilan dan juga penghasilan mitra. Peningkatan ditunjukkan pada Gambar 12.

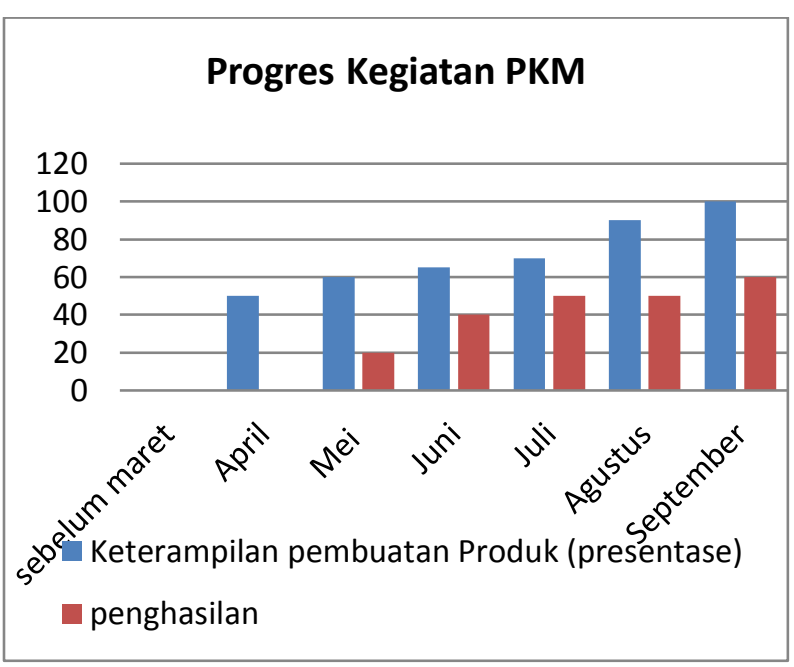

Gambar 12. Grafik progres kegiatan PKM

Pada Gambar 12 dapat diketahui bahwa terdapat peningkatan keterampilan dan penghasilan mitra setelah dilakukan kegiatan PKM. Diketahui sebelum Maret keterampilan masih belum ada dan juga penghasilan tambahan mitra juga belum ada.

Pada bulan April telah terjadi peningkatan keterampilan sekitar 50 persen dan belum ada penigkatan penghasilan. Pada bulan mei yang bertepatan dengan bulan puasa terdapat peningkatan keterampilan karena mitra belajar untuk menerima pesanan pada bulan puasa. Pada bulan juni terdapat 
peningkatan keterampilan setelah dilakukan pendampingan I untuk melatih pelaksanaan produksi mitra. Pada bulan Agutsus belum terdapat peningkatan penghasilan, namun terdapt peningkatan keterampilan dalam pembuatan produk maupun kegiatan pemasaran. Pada bulan September, terdapat peningkatan keterampilan hingga $100 \%$ karena mitra telah mampu memproduksi semua produk yang dikemabangkan.

Berdasarkan Gambar 12 dapat disimpulkan bahwa terdapat peningkatan pendapatan dari mitra. Peningkatan pendapatan ini mengarah pada peningkatan gerakan pembangaunan masyarakat. Sehingga dapat disimpulkan kegiatan pelatihan ini mitra mampu berwirausaha yang pada akhirnya dapat mengembangkan pembangunan masyarakat khususnya dalam bidang pengetahuan dan ekonomi. Asri dan Komar (2018) menjelaskan salah satu gerakan pembangunan masyarkat dalam upaya mengubah taraf kehidupan masyarakat ke arah yang lebih baik dan mandiri dengan melalui beriwausaha.

\section{PENUTUP}

\section{Simpulan}

program kemitraan masyarakat dapat disimpulkan kegiatan terdiri dari kegiatan analisis kebutuhan, persiapan, pelaksanaan, serta evaluasi dan pendampingan. Hasil kegiatan PKM masyarakat cukup antusias dan mampu mengolah Telo Ungu gunung Kawi menjadi olahan lain seperti stik, brownies dan bakpia telo ungu. Kendala yang ditemui dalam pengembangan kewirausahaan telo ungu ini, khususnya adalah pengembangan SDM mitra yang cukup sulit dikembangkan.

\section{Saran}

Saran kegiatan ini adalah dilakukan kegiatan yang lebih mengarahkan pada pengembangan SDM mitra sebelum dilakukan kegiatan program kemitraan masyarakat. Serta perlunya kegiatan pelatihan pemasaran kepada mitra untuk meningkatkan penjualan dan keberlangsungan wirausaha.

\section{Ucapan Terima Kasih}

Terima kasih kami sampaikan pada Kemenristekdikti dan Universitas Kanjuruhan yang telah memberikan dukungan secara finansial dan moral atas terselsesainya program kegiatan maysarakat ditahun 2019. Ucapan terima kasih juga kami sampaikan kepada kepala desa Wonosari, Ketua PKK desa Wonosari, Kepala UKM Ketela Ungu Gunung Kawi dan Ibu Ibu PKK Desa Wonosari.

\section{E. DAFTAR PUSTAKA}

ariani, M. (2010). Analisis Konsumsi Pangan Tingkat Masyarakat Mendukung Pencapaian Diversifikasi Pangan. Gizi Indon, 33(1), 20-28.

Asri, M., Komar, O. (2018). Pemanfaatan Hasil Pelatihan Keterampilan Dan Peran Pendamping Dalam Meningkatkan Kemandirian Usaha (Studi Pada Program Desa Vokasi Di Desa Cisaat Kecamatan Ciater Kabupaten Subang Provinsi Jawa Barat). (1-14)

Haliza, W., Kailaku, S. I., \& Yuliani, S. (2017). Penggunaan Mixture Response Surfa Ce Methodology Pada Optimasi Formula Brownies Berbasis Tepung Talas Banten (Xanthosoma Undipes K. Koch) Sebagai Alternatif Pangan Sumber Serat. Jurnal Penelitian 
Pascapanen Pertanian, 9(2), 96.

Herryanto, M., \& Toly, A. A. (2013). Pengaruh Kesadaran Wajib Pajak, Kegiatan Sosialisasi Perpajakan, Dan Pemeriksaan Pajak Terhadap Penerimaan Pajak Penghasilan Di Kpp Pratama Surabaya Sawahan. Tax And Accounting Review, 1(1), 125-133.

Kamil. (2010). Model Pendidikaan Dan Pelatihan: Konsep Dan Aplikasi. Alfabet: Bandung.

Machmud, N. F., Kurniawati, N., \& Haetami, K. (2012). Pengkayaan Protein Dari Surimi Lele Dumbo Pada Brownies Terhadap Tingkat Kesukaan. Jurnal Perikanan Kelautan, 3(3), 183-191.

Pranata, K. B., Ghufron, M., \& Tri, M. P. (2018). Peningkatan Produksi Dan Kualitas Produk Olahan Camilan Keripik Ketela Di Kec. Trawas, Kab. Mojokerto. Journal Of Innovation And Applied Technology, 4(1), 700-703.

Putri, S. (2013). Kajian Aktivitas Indeks Glikemik Brownies Kukus. Jurnal Kesehatan, Viii.

Suladra, M. (2017). Optimasi Ermentasi Tepung Singkong Dan Aplikasinya Pada Pembuatan Makanan Stik. Agrotech, 2(1), 61-68.

Sugiharto, E. (2007). Masyarakat Nelayan Desa Benua Baru Ilir. Epp, 4(2), 32-36.

Sulistiawati, R. (2012). Pengaruh Investasi terhadap Pertumbuhan Ekonomi dan Penyerapan Tenaga Kerja Serta Kesejahteraan Masyarakat di Provinsi di Indonesia. Jurnal Ekonomi Bisnis Dan Kewirausahaan, 3(2-3), 271-285.
Sumpah, J., \& No, P. (2015). Karakteristik Organoleptik Brownies Dengan Campuran Tepung Mocaf Dan Tepung Ketan Hitam Dengan Variasi Lama Pemanggangan. XXVII(2), 272-280. 